Till Mostowlansky*

\title{
Building bridges across the Oxus: language, development, and globalization at the Tajik-Afghan frontier
}

DOI 10.1515/ijsl-2017-0021

\begin{abstract}
In this article I set out to explore the Tajik-Afghan frontier in Tajikistan's Gorno-Badakhshan region as a "contact zone" in which different actors engage in communicative encounters. Against this backdrop I take the construction of bridges across the Tajik-Afghan border river as a point of departure to analyse how these actors envisage processes of globalization. Following Pennycook, I argue that a focus on language as local practice reveals that the Tajik-Afghan frontier is marked by a high degree of different languages, but also by multiple meanings within and beyond these languages. As a result I maintain that highlighting the locality of languages at the Tajik-Afghan frontier provides an opportunity to frame language as tied to specific communicative encounters in semiotized time and space.
\end{abstract}

Keywords: global connections, local practice, language ideology, Tajikistan, Afghanistan

\section{Introduction}

On a cold Sunday morning in November 2002 three men gather on the northern bank of the Panj, the river that marks the Tajik-Afghan border. They walk over a newly constructed bridge, cut ribbons, step up onto a stage, and then address a large crowd of people listening on both sides of the river. In their speeches in Tajik, Dari, and English (which are informally translated and paraphrased into Pamir languages), ${ }^{1}$ the three men refer to the bridge as crucial for re-establishing ties between Tajikistan and Afghanistan after the isolation of Soviet rule, for

1 Tajik and Dari are both south-western Iranian languages and are mutually intelligible. The Pamir languages are of south-eastern Iranian origin and not comprehensible to a Tajik or Dari speaker without prior experience or language training. However, there is also great diversity within the Pamir languages, which include Bartangi, Ishkoshimi, Khufi, Roshorvi, Rushoni, Sariqoli, Shughni, Wakhi, and Yazghulomi. Not all Pamir languages are mutually intelligible (see Dodykhudoeva 2002; Bahry 2016).

*Corresponding author: Till Mostowlansky, Hong Kong Institute for the Humanities and Social Sciences, The University of Hong Kong, Hong Kong, Hong Kong, E-mail: mostow@hku.hk 
economic development in the region, and for renewed interaction between disconnected communities on each shore of the river (AKDN 2002; Tasneem 2002).

The three men inaugurating the Tem-Demogan bridge in Tajikistan's GornoBadakhshan Autonomous Region (GBAO) were the Tajik president Emomali Rahmon, the then vice-president of Afghanistan Hedayat Amin Arsala, and the current Imam of the Nizari-Ismaili Muslims, Prince Shah Karim Al Hussaini Aga Khan IV. ${ }^{2}$ Since 2002, they themselves and their envoys or successors have opened a series of new bridges across the river Panj, one of the main tributaries of the famous Amu Darya, or Oxus, as Western historiographers have called it until very recently (Curzon 2005 [1896]; Toynbee 1961). See Figure 1.

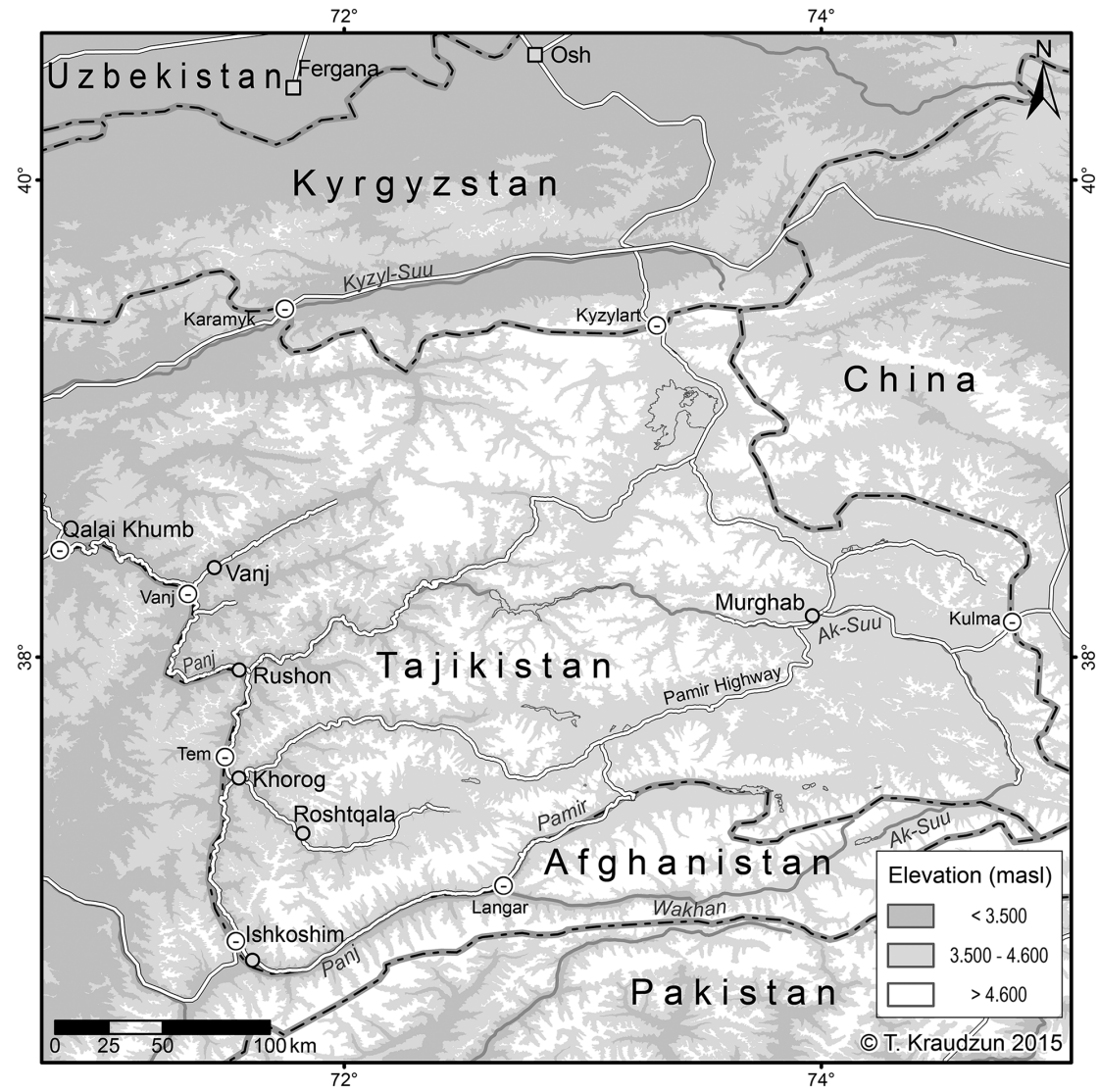

Figure 1: The border between Afghanistan and Tajikistan along the river Panj.

2 Throughout the article I use pseudonyms for my interlocutors and only state the actual names of well-known public figures. 
In the course of this ongoing attempt to reconnect Tajikistan and Afghanistan, which had been separated by Soviet boundary-making and enforcement measures along the river for most of the twentieth century, the construction of the bridges constitutes the most visible, material aspect of the endeavour. However, the process of planning, building, opening, and living with these bridges has also involved encounters between diverse actors bringing with them varying ideologies expressed in different languages. Questioning the image of globalization as a smooth "flow of goods, ideas, money, and people", Tsing (2005: 5) sees such encounters as marked by "friction", which she defines as "awkward, unequal, unstable, and creative qualities of interconnection across difference" (Tsing 2005: 4). Following Tsing, in this article I seek to analyse the communicative encounters that the construction of bridges between Tajikistan and Afghanistan has triggered. In this respect I build on existing social science research on borderlands in different parts of the world (e.g., Baud and Van Schendel 1997; Omoniyi 2004; Evans 2010; Van Schendel and De Maaker 2014), and in the former Soviet Union in particular (e.g., Muth 2014a; 2014b; Reeves 2014). Inspired by the work of Pennycook (2010: 133) I also explore the question of how specific linguistic resources "are drawn on for different effects", by whom and under which circumstances. To do so, I build on multi-sited ethnographic fieldwork (Marcus 1995) conducted in Tajikistan between 2008 and 2013, including recorded interviews, as well as on data from public discourse and NGO reports.

In order to prepare the ground for the analysis of my data I first introduce the conceptual framework of this article. Then I focus on the public discourse surrounding the construction of the bridges and present examples, based on my ethnographic fieldwork, of lives in the region that are variously affected by and entangled with the history of bridge construction. Finally I attempt to go beyond the construction of bridges along the Panj to explore the meaning of "language as a local practice” (Pennycook 2010) at the Tajik-Afghan frontier from a broader perspective.

\section{Approaching the frontier}

Tsing's (2005) notion of "friction" is closely linked to a polysemic understanding of communicative encounters. Accordingly, interventions such as the construction of bridges across the river Panj in Tajikistan are not essentially and a priori endeavours of economic, ideological, or geostrategic significance. While they reconfigure ongoing social and political processes, such interventions also draw upon and are (continuously being) reworked in specific locales. In order to emphasize the communicative nature of these encounters, I conceptualize 
such locales as “contact zones" in which, following Clifford (1997: 7), "the making and remaking of identities" takes place "along [...] policed and transgressive intercultural frontiers".

Clifford (1997) bases his definition of "contact zone" on the work of Pratt (2008 [1992]: 8), who borrows the term from research on contact languages and employs it as a substitute for the value-laden category "colonial frontier". Pratt argues that such "frontiers" are always constituted with respect to Europe (or other centres of power) and thus are already the outcome of historically produced asymmetries. She maintains that we should instead look at interactions within such zones as shifting "the center of gravity and the point of view". Pratt (Pratt 2008 (1992): 8) sees the benefit of looking at a "contact zone" in the fact that "it invokes the space and time where subjects previously separated by geography and history are co-present, the point at which their trajectories now intersect”.

The construction of bridges across the river Panj is a tangible example of such a point of intersection and allows for exploration in different directions. In this regard, bridge construction is salient not just due to its vivid materiality, but also because it evokes communication on various scales in "semiotized space and time" (Blommaert et al. 2014: 3; see also; Blommaert 2007). In the course of these communicative encounters different actors address different audiences in different languages, enacting a multi-layered set of identities often with reference to specific ideologies and with unknown outcomes. As a result the local undergoes transformations that include not simply a change of context, but a relocalization in the sense of a reassembling of the known. Within this framework, and following Pennycook (2010: 4-5), language needs to be conceptualized as local practice that is not only related to place, but "must always be understood in terms of its embeddedness in locality". Thus, language as local practice furthermore refers "to the ways in which any understanding of the locality of language must also encompass an appreciation of the locality of perspective, of the different ways in which language, locality and practice are conceived in different contexts".

Taking Pennycook's point seriously means acknowledging that we cannot look for a pre-defined set of languages which coincidentally meet at the opening of bridges between Tajikistan and Afghanistan. Rather, we should focus on how these languages are constantly under construction, how they purport different ideologies, and how they coincide, intersect, and drift apart. As a consequence, Tajik is not simply Tajik, English not simply English, Russian not simply Russian, and "local" languages perhaps less local than we think. From such a perspective there are always different projects of English, Kyrgyz, Russian, Shughni, Tajik, and so forth in the making, depending on who speaks to whom, when, and in what "contact zone". 
In the following I build on this point by organizing my data according to specific, interrelated communicative encounters. In this regard it is clear that I can only present brief extracts from such encounters that I perceive as central to the understanding of broader processes of the co-construction of language in the localities under analysis. I furthermore restrict my analysis to communicative encounters that occurred on the Tajik side of the border region, in Tajikistan's Gorno-Badakhshan Autonomous Region (GBAO). Localities in south-western Tajikistan as well as on the Afghan side of the border are not within the scope of this analysis.

\section{Let the construction begin}

Looking at the Tajik-Afghan frontier in Gorno-Badakhshan as a "contact zone" also means including moments of disconnection and the reorganization of contact on different scales. Going back in history, wars, conflict, and imperial boundary-making were at the heart of these transformation processes. While certainly not the beginning of these dynamics, the latter part of the nineteenth century is a potential point of departure for understanding why today's actors invoke the historical references they do when talking about regional changes and the reorganization of space. In this regard, it is important to note that the Tajik-Afghan frontier in Gorno-Badakhshan used to be part of a colonial border region that was created on the basis of wars and treaties between the Russian Empire, the British Empire, and Afghanistan in the course of the late nineteenth century (Barfield 2010: 146-154; Saikal 2012: 31; Straub 2013).

In the process of establishing rule in Central Asia in the 1920s, the Soviets followed colonial boundary-making and defined the territory north of the Panj as part of the newly founded Tajik Soviet Socialist Republic. This delimitation was finalized in 1929 and provided the framework for an independent Tajikistan after the dissolution of the Soviet Union in 1991 (Bergne 2007: 131). For people living at the Tajik-Afghan frontier, the Soviet distinction between a friendly socialist and a hostile capitalist realm carved out by the river Panj had actual, often dramatic consequences. In order to prevent "contact" in the form of flows of "people, goods and money”, the border was kept "under lock and key” (na zamok) (Shaw 2011: 332). Previous practices, including trade, inter-marriage, and travel across the river, changed and were organized along points of reference within the Tajik Soviet Socialist Republic and other places in the Soviet Union. In addition, Soviet modernization programmes in various fields of society such as infrastructure, education, and health care were designed to create a gap between the "modern" Tajik and the "backward” Afghan sides of the Panj (Manetta 2011; Remtilla 2012: 45-55). 
The establishment of a militarized Cold War boundary in Gorno-Badakhshan did not imply that political and economic ties between the Soviet Union and Afghanistan were non-existent. In fact, recent research shows that the Soviet Union was a major development partner for Afghanistan from the 1950s onwards (Robinson and Dixon 2013; Nunan 2016). However, individual links and personal cross-border relations were prohibited on a local level in Gorno-Badakhshan. This situation only began to change after the dissolution of the Soviet Union in 1991 and the beginning of the Tajik civil war, which ravaged the country from 1992 to 1997 (Epkenhans 2014; see also Nourzhanov and Bleuer 2013: 323-335). While militiamen, drug traffickers, and refugees crossed the river for different purposes during that time, in the past fifteen years international aid and development interventions have offered new opportunities for "contact", including the construction of bridges and trade terminals.

The question of language at the Tajik-Afghan frontier has been highly politicized since the early days of Soviet rule. In order to ensure, at least pro forma, a coherent Tajik Soviet Socialist Republic based on a majority of Tajik speakers, Soviet planners showed little appreciation for the distinct Pamir languages that are dominant on both banks of the Tajik-Afghan frontier (Bergne 2007: 62). Despite the fact that Soviet ethnographers observed the emergence of a common "Pamiri" identity among speakers of Pamir languages as early as 1935 (Hirsch 2005: 279), Pamir languages received no official status beyond the right of "usage" (and therefore neither a standardized script nor recognition as a language of instruction in schools) (Straub 2014: 177). Moreover, even though speakers of Pamir languages were officially defined as Tajiks in the Soviet Union, many inhabitants of Gorno-Badakhshan developed a particular affinity for Russian, which used to be the dominant language of education in the region and was promoted by Soviet authorities through generous "Moscow provisioning" (Moskovskoe obespechenie) in their efforts to integrate the borderland into a larger Soviet framework (Mostowlansky 2017).

In Tajikistan, as in many parts of Central Asia and indeed the former Soviet sphere of influence in its entirety, the later Soviet period and the eventual dissolution of the Union brought with them changing attitudes and policies towards the Russian language (Pavlenko 2008: 282; Kellner-Heinkele and Landau 2012: 9-12, 173-197). In the following period, in independent Tajikistan a centralized concept of nationhood nurtured by Tajik language and culture emerged. During the Tajik civil war, this concept of nationhood intersected with acts of violence that drew on regional and linguistic identities. For instance, Epkenhans (2016: 346) notes that in the war-torn capital Dushanbe, male passengers on public buses were tested by militiamen in order to identify their origin. The passengers were forced to pronounce specific Tajik words while the 
militiamen checked for a Pamiri accent. Those men identified as coming from Gorno-Badakhshan were arrested as members of the opposition and executed.

Similar memories are still vivid in Gorno-Badakhshan, where they have become entangled with differing evaluations of Tajik as a language, but also with the state as a whole. A new law on language, introduced in Tajikistan in 2009, places a strong emphasis on Tajik as the sole language of administration and has contributed to this process (Kellner-Heinkele and Landau 2012: 178; Mostowlansky 2017: 118-122; Bolander 2016). In addition, frequent unrest and violence in Gorno-Badakhshan since 2012, particularly in its administrative centre Khorog, have rekindled ambiguous attitudes towards the state and Tajik as its "preferred" language. In the course of my fieldwork in Khorog and in the eastern part of Gorno-Badakhshan, many of my interlocutors referred to these civil war and post-civil war events when talking about the Tajik language. In this regard, they often distinguished between an "artificial" (iskusstvennyi) Tajik that is spoken by state officials (and therefore linked to war atrocities) and a "beautiful" (khoshroi) Tajik that can be found in poetry, songs, and religious texts. Thus, to my interlocutors in Gorno-Badakhshan, it mattered a great deal who spoke to them, how, and on the basis of which common history.

\section{The president comes by}

Against the backdrop of Tajik civil war history, a presidential visit to GornoBadakhshan is not only a political event; it also reverberates in regional, ethnic, religious, and linguistic identities. Accordingly, the speeches that President Emomali Rahmon gives in Gorno-Badakhshan are designed for specific audiences with particular expectations and take into account the region's multilayered heterogeneity. For instance, in 2010 Rahmon urgently called for national unity in the district of Murghab, which is mostly inhabited by Kyrgyz-speaking Sunni Muslims. ${ }^{3}$ With Kyrgyz and Tajik being mutually unintelligible, the president found himself in the absence of a common linguistic identity. He

3 According to data from 2015 provided by the local government in Murghab, the district's total population of around 15,000 consisted of 12,000 Kyrgyz and 3,000 Tajiks. While the category Kyrgyz means that these are inhabitants who speak Kyrgyz, a Turkic language of the Kipchak branch, as their first language (Karabaev and Ahn 2016), the Tajiks in Murghab are almost exclusively speakers of Pamir languages (predominantly Bartangi and Wakhi). Despite Tajik being the language of administration in Murghab, Kyrgyz, Russian, and Pamir languages are in fact much more commonly used in most spheres of life in the district. 
therefore delivered his speech in Tajik but based it on a historical narrative of intermarriage between Kyrgyz and Tajiks (Mostowlansky 2012: 254). By referring to common kin and religious identity (Sunni Islam), Rahmon attempted to bridge the "friction" between him (representing the Tajik state) and his Kyrgyz audience, most of whom could not follow the speech without informal translation. Such locally adapted encounters can also be observed with regard to other public events, including ceremonies celebrating the opening of bridges across the Panj. Since 2002 a number of bridges have been completed at different points along the river stretching from western Tajikistan to the south-eastern part of Gorno-Badakhshan, thus providing the Tajik president with opportunities to establish contact with diverse audiences.

On 16 August 2011, President Rahmon participated in the opening of the fourth bridge across the Panj, which cost the Aga Khan Foundation US \$2.6 million. The project also includes a small German-financed cross-border market (AKDN 2011). The bridge is located in the district of Vanj, which is part of GornoBadakhshan but whose population differs from the region's majority with regard to first language and religious identity. While most inhabitants of GornoBadakhshan speak a range of Pamir languages and are Ismaili Muslims who identify with the Aga Khan, people in Vanj are predominantly speakers of Tajik and Sunni Muslims (like most other Tajiks in the country). Thus, Rahmon addressed the audience in Vanj in Tajik as follows (Example 1):

(1) Dear compatriots, respected guests and participants! I am very glad that I have once again the opportunity to meet you - hospitable, nice, conscientious, and patriotic people of the paradisal district of Vanj. Above all I would like to tell you that every time I come here I feel happiness and satisfaction based on your true support for the policies of the state and the government of Tajikistan.

(Prezident 2011) ${ }^{4}$

In his speech Rahmon expressed intimacy towards his audience in Vanj based on a form of assumed political loyalty that is ultimately rooted in ethnic Tajik sameness. This is lexicalized through the use of the term "compatriots" (hamvatanon) in the salutation, the expression of gratitude for what the president refers to as "true" (samimona) support, and the persistent use of positive adjectives to describe the people as patriotic and the district of Vanj as "paradisal" (bihishtoso). In this sense, the president came to say that the Vanjis' alignment with state policies can be taken for granted because, in

4 All translations by the author unless otherwise noted. 
this particular setting, they represent the ideal-type citizens who are "native" in Tajik and follow Sunni Islam. However, in everyday Gorno-Badakhshan, the Vanjis' position is actually much more diverse than the speech would lead one to assume: Vanjis share regional traits of Pamiri identity with the majority of Pamiris, although, as stated above, they differ with regard to first language and religious identity.

Differences between Vanjis and other Pamiris can become central in everyday encounters, but they often gain particular importance in official settings in the course of which the acknowledgment of "national unity" (vahdati milli) stands at the forefront. Such instances not only highlight how ideal-type citizens should behave but also how they should not. In this regard, a presidential speech (Example 2) that Rahmon gave during a public meeting (muloqot) in conflict-torn Khorog in September 2012 stands in contradistinction to his appearance in Vanj:

(2) [T]he negative events that took place in Khorog [in July 2012] show that the students' education in the spirit of patriotism, loyalty towards national and state interests, respect for the constitutional order, and observance of existing laws is on a very low level in particular schools - especially in the city of Khorog.

(Prezident 2012)

While mitigated via reference to the students (instead of a more direct you), President Rahmon's criticism comes across loud and clear and is bolstered by pointing to loyalty, respect, and observance, all positive, desirable qualities that are represented as lacking in this context. This short extract of Rahmon's speech can be read against the background of a multi-faceted conflict between militias in Khorog (and their followers) and government forces that has lingered since the Tajik civil war. The conflict has been played out in different realms, including political power and regional identities (Heathershaw 2009: 20-40), religion (Mostowlansky 2016) and, not least, linguistic differences. Thus in his speeches President Rahmon's focus on a larger framework of "national interests" not only included the distinction between loyal and disloyal people and places, but also showed little understanding for differences between a normative state ideology (in which the Tajik language plays a central role) and divergent local identities and practices. Going back to the example of the ceremony for the opening of the bridge in Vanj in August 2011, this becomes clear in the way Rahmon first asserted and emphasized the loyalty of his local audience, but then immediately moved to an evaluation of the bridge's advantages from an official perspective, as perceived from Tajikistan's capital Dushanbe (Example 3): 
(3) With the construction of the mentioned objects [the bridges] and with the repair work of Afghanistan's northern roads, our country gains access to the shortest transport route to important warm-water ports on the Persian Gulf and the Indian Ocean. Our country will furthermore be able to connect to important and developing world regions such as western Asia, South Asia, and South East Asia, which is not only of great economic and communicational importance, but also of political and geostrategic significance for the Republic of Tajikistan and the Islamic Republic of Afghanistan.

(Prezident 2011)

Apart from grand economic opportunities in a globalized Asia, Rahmon's speech also touched upon the hope of a close relationship with Afghanistan that ought to be based on an overarching "Persianate" connection (Hodgson 1977: 46; Fragner 1999) between the two states rather than on local affinity between people on both banks of the Panj (who at specific points speak Tajik as a first language, but predominantly live in multilingual settings in Gorno-Badakhshan) (Example 4):

(4) In addition, Tajikistan has always paid special attention to deepening the good, constructive, and reciprocal connections with its close neighbours and their people, including friendly and brotherly Afghanistan, which shares with us linguistic and cultural similarities.

(Prezident 2011)

In many of his speeches, Rahmon positions himself as the person responsible for the "national", for countrywide unity and alignment (Heathershaw 2009: 70), and in this particular case for broader links between Persian-speaking Tajikistan and Afghanistan (and their Persian varieties Tajik and Dari). With audiences of diverse (linguistic) backgrounds throughout the country, such an approach can coincide with local needs and aspirations, but also has the potential to provoke "friction" and a sense of disconnectedness among listeners. Thus, when it comes to showing concern for those local needs and aspirations that do not fit into the framework of a Tajik-centric state ideology, other actors often enter the stage. In many localities in Ismaili-dominated Gorno-Badakhshan, the man taking this place is the Aga Khan, who is not only the current Imam of the Nizari-Ismaili Muslims, but also the chairman of the Aga Khan Development Network (AKDN), which is largely responsible for bridge construction across the Panj as well as for numerous other development projects in the region. 


\section{A princely flow of goods}

Prince Shah Karim Al Hussaini Aga Khan IV entered different scenes in Tajikistan at an early stage of the civil war in 1993. To people in GornoBadakhshan, the Aga Khan is the man who saved them from starvation with the help of humanitarian aid; to Ismailis in Tajikistan, he is not only an earthly provider but also the spiritual leader; and to representatives of the government, he seems like a double-edged sword, both a political-economic necessity and potential ally of the Pamiri opposition-cum-religious other (Steinberg 2011: 129-130). It is against this backdrop that one can read the final words of President Rahmon's speech in Khorog (see Example 2). In his speech, the president calls for patriotism and action against those who work against national unity, the "outside forces and enemies of the nation and the state" (nerūhoi beruna va badkhohoni millatu davlatamon), and he reminds his audience that it was actually he who "brought" the Aga Khan to Gorno-Badakhshan for the first time in 1995 (Oghokhoni IV ... ovarda budam) (Prezident 2012).

The act of having "brought" the Aga Khan to Gorno-Badakhshan served President Rahmon as a tool to claim legitimacy in the region, and can be interpreted as an attempt to signal both benevolence towards and control over his audience. Yet to a majority of people in Gorno-Badakhshan it also makes it clear that the president does not represent what the Aga Khan stands for as a "social, political and spiritual leader" (Steinberg 2011: 10). As global connections in the region have quickly moved away from a Soviet framework in the past twenty years, the president has virtually "outsourced" concerns for the local to a man who resides in France and addresses his Badakhshani audiences in English. This points to a differentiation of scales whereby "national interests” are attributes of President Rahmon, but both global and local matters are those of the Aga Khan. Accordingly, we can understand how popular encounters with the Aga Khan, which occur in English and are simultaneously translated into Tajik, are linked to rather different language ideologies than the ostensibly "monolingual” Tajik meetings with Rahmon.

On 31 October 2006, for instance, the Aga Khan, along with President Rahmon and high-ranking officials from both Afghanistan and Tajikistan, participated in the opening ceremony for the bridge in Ishkoshim at the southern tip of Gorno-Badakhshan. His speech was thus situated in a multilingual setting, both with regard to the speakers and the particular locality of Ishkoshim, where Pamir languages and Tajik intersect in everyday encounters. In his speech, which he delivered in English and which was simultaneously translated into Tajik (and informally into Pamir languages by the guests), the Aga Khan referred to bridge construction as an endeavour with both moral and economic 
dimensions. Depicting the tight intertwining of these dimensions, he introduced his speech with the following words (Example 5):

(5) It has always seemed to me that bridges are among the most powerful and important symbols in human society - symbols of connection, of cooperation and of harmony. When harmony breaks down and conflicts ensue, the destroying of bridges is usually among the most urgent targets. But when peace and healing come, then it is the construction and rehabilitation of bridges that marks our progress.

(AKDN 2006)

The Aga Khan's metaphor of the bridge as a prime indicator of war and peace, backwardness and progress, was as much a multi-layered reference to colonial boundary-making and Soviet hegemony in the region as it was a subtle reference to the Tajik civil war and the end of the Taliban regime in Afghanistan. In this sense, the bridge stands for the materialized morality of an alternate economicpolitical vision that draws on unimpeded mobility and a free flow of goods and people (Example 6):

(6) Each of the bridges I have mentioned has had a considerable moral and symbolic value, inspiring a spirit of confidence, progress and hope. But these projects also have a very concrete economic value, allowing for a substantial expansion of productive exchange. People in both countries are granted unprecedented access to markets beyond their immediate frontiers. Goods originating in Pakistan can now make their way to Tajikistan. Products from China now have a fast road transit to Afghanistan.

(AKDN 2006)

In this idealized version of capitalism, the emphasis on the local is key because the economy is not just seen as involving depersonalized interactions between strangers, but as building upon the convergence of neighbouring people. In his speech in Ishkoshim, the Aga Khan emphasized this as follows (Example 7):

(7) Links and meeting places created by the bridges do more than simply facilitate commerce. We exchange questions and answers. We trade in products, but we can also trade in ideas. Communities on each side of the border will know one another better and be better able to help one another grow, prosper and share the lessons of life.

(AKDN 2006) 
In parts of his speech, the Aga Khan drew on the conceptual metaphor of "conversation is economy". The goods in this metaphor were questions, answers, and ideas. With his words in English, the Aga Khan thus enacted the very metaphor to which he referred. While "trade in ideas" and "sharing" in non-material ways are integral to the Aga Khan's humanitarian philosophy, the expression of the wish to go beyond national borders, not only economically but also spiritually, coincides with the fact that in many places in Gorno-Badakhshan people on both sides of the Panj are Ismailis. From an official perspective as conveyed by the Aga Khan, they are therefore in need of unity and ideally part of a network of local Ismaili communities around the world (Steinberg 2011). Thus, building bridges across the Panj not only serves the economic interconnectivity of Tajikistan and Afghanistan, of Central and South Asia, but also the (re-)connection of people with shared religious (Ismaili) and linguistic (Pamir languages/Tajik) identities who were separated in the course of colonial and Cold War boundary-making.

The Aga Khan's ideal of connectivity touches upon dimensions of globalization that go beyond the mere commodification of human interaction and mobility. He propagates the distinct vision of a reunion between the formerly disconnected people of the Tajik-Afghan frontier. In many places in Gorno-Badakhshan this envisaged reunion does not just involve the development of economic relations, but is also linked to the fact that the Aga Khan considers the people on both banks of the river to be part of his worldwide Nizari-Ismaili community (Jamat). From such a perspective English serves, on the one hand, as the language of economic globalization and development. On the other hand, to people in the region it is also the language spoken by the Aga Khan as the current Imam of the NizariIsmailis and as a social entrepreneur who stands for a humanitarian philosophy with pluralism at its heart (Bolander 2016, this issue).

In the following section I will turn to ethnographic examples from my fieldwork that show how President Rahmon's and the Aga Khan's visions and practices reverberated among my interlocutors at the Tajik-Afghan frontier. Drawing on data from participant observation and interviews, I will first show how my interlocutors assessed the forms of "contact" that these visions and practices entailed. I then seek to explore how my interlocutors positioned themselves within subsequent processes of change and to analyse the consequences this has for the notion of language as local practice.

\section{Two tales of a river}

Talking about the river Panj and the newly constructed pathways bridging it is not an easy task in Gorno-Badakhshan. The river is an acknowledged conduit of 
opium and heroin trafficking from Afghanistan to Tajikistan (De Danieli 2011). In addition, rumours circulate in the region that more money was spent on the construction of the bridges than was necessary, and that some people got rich as a result. This makes discussing the Panj a complex matter that is not only linked to discourses of danger, but also to dangerous practices. Consequently, my interlocutors in the region hardly ever focused on the river or the bridges, but rather mentioned them in subordinate clauses and on the sidelines of our conversations.

Thus it is not surprising that even Shahriyor, an elderly engineer who lives in close proximity to the Panj and who is passionate about the construction of infrastructure, did not talk much about the bridges when I met him in 2013. By that time, Shahriyor had personally visited several of the bridges and was aware of the speeches and visions that had come with their openings. In the course of our conversation, which we held in Russian and Shughni, I asked Shahriyor about his opinion on upcoming bridge projects. He replied as follows (Example 8):

(8) Now I think they are finishing [the bridge] in Shurobod. And there are bazaars. What does that tell us? It tells us about development. It tells us that people trade among one another, that they eat and that they earn money. If [the bridge] were to be closed, that would be very bad. In fact these bridges are being built at the Aga Khan's expenses. He is our Imam. $\mathrm{He}$ is the Imam of the Ismailis. Tajikistan didn't give a penny for the road construction. The bridges were built at the Aga Khan's expenses. ... A lot of schools were built, too. Hospitals were repaired at the Aga Khan's expenses. Our great Imam! He is our Imam.

As our conversation progressed Shahriyor repeatedly stressed that he considered the newly established links to Afghanistan to be symbols of development (razvitie), primarily because the Aga Khan had been involved in their construction. Tajikistan, represented by President Rahmon, had contributed nothing but the permission to open the border. At the same time - and this was an important argument throughout our discussion - Shahriyor insisted that the bridges should have never been constructed and the border should have stayed closed. In this regard, Shahriyor defined himself as coming from a "Communist family", with his father having been such a "serious Communist" that "if Lenin had told him not to sleep with his wife, he would have not slept with her”. It is against this backdrop that one can read Shahriyor's reply to my question about how he related to the people on the Afghan side after the opening of the bridges (Example 9): 
(9) They didn't do anything. ... They're just enjoying [the bridge]. ... They are a different nation. They are not like us ... because there's still socialism in our system. In fact, we haven't broken the [socialist] system yet. In fact, it's like we were going down a different road than they were, and the old system remains.

Shahriyor's distinction between a socialist "us" on the Tajik side of the river and a rather undefined, vaguely backward "them" on the Afghan side of the Panj can be seen as a result of the Soviet project of modernization in Gorno-Badakhshan. In the course of this project the state attempted to integrate the border region into a larger Soviet framework through the building of infrastructure, "Moscow provisioning", and mobility (Bliss 2006: 247-270). At the same time, this process enforced the development of dichotomies such as socialist vs. capitalist, progressive vs. backwards, and civilized vs. barbaric along the Tajik-Afghan border river. Manetta (2011), on the other hand, maintains that these dichotomies have also led to a positive depiction of the Afghan side of the border region as standing for the primitive, yet purer part of the Tajik side's own past (see also Remtilla 2012: 130-147).

To many of my interlocutors at the Tajik-Afghan frontier, the fact that they shared linguistic and religious identities with those on the other side of the Panj mattered little in their everyday lives. Except for infrequent encounters with Afghans in the context of cross-border markets (Amidkhonov 2013; Maertens 2014), "contact" with them was mostly mediated by the Aga Khan's speeches and "edicts" (farmon), as well as by projects of AKDN institutions. In fact, my interlocutors in Khorog stated that they were more likely to encounter Afghan citizens from other parts of Afghanistan than those from just across the river. Hence, Shahriyor's reference to socialism as "in our system" is not only an indicator of nostalgia for the past commonly reflected in post-socialist theory (Nadkarni and Shevchenko 2004; Todorova and Gille 2010). It also refers to at least three different scales: despite underscoring his identity as an Ismaili, Shahriyor framed his argument of a Tajik "us" and an Afghan "them" in connection with a national scale and projects of Tajik nation-building. At the same time his reference to "intrinsic" socialism is also a description of current connectivity and spatial organization in Gorno-Badakhshan, which as a region still relies on Russian as the language of inter-ethnic communication and is economically highly dependent on labour migration to other parts of the former Soviet Union (Khuseynova 2013: 32).

My interlocutors linked Afghanistan to general anxiety and perceived the opening of the border as a potential threat to Gorno-Badakhshan. They did so in contrast to the differing visions of globalization conveyed by President Rahmon 
and the Aga Khan, drawing on the distinction between a modern "us" and a premodern "them". Together with the common Soviet past, the experience of modernization, and knowledge of Russian, delimitation from hostile Afghanistan was among the most frequently mentioned traits of a GornoBadakhshani identity that spanned ethnicity, language, and religion.

In this regard even in Murghab, a predominantly Kyrgyz-speaking Sunni town located some 300 kilometres east of Khorog on the far eastern edge of Gorno-Badakhshan, bridge construction across the Panj was a hotly debated topic in the course of my fieldwork. For instance, during an interview on family networks in 2013 with Bakytgül, a female healer in Murghab, she mentioned Afghanistan as a place of ancestral Kyrgyz kin relations. However, she also emphasized that these links had ceased to exist in the course of early Soviet rule. Baktygül assessed the reconnection between Tajikistan and Afghanistan and the construction of the bridges as negative and misguided initiatives. In the course of our conversation in Kyrgyz she said (Example 10):

(10) Many bridges are built here leading to Afghanistan. [The Aga Khan] helped because he thought people there would live in peace. But they don't live in peace. There are mujaheddin over there. They want war and continue to come again and again.

During the interview, Baktygül emphasized her appreciation for the Aga Khan, whose institutions had secured livelihoods in Murghab during the civil war despite the fact that only a minority of the town's inhabitants are Ismaili. At the same time, she considered the opening of the border with Afghanistan a naïve and ill-informed act. In her view, Afghanistan was a dangerous place that should be kept at distance, a condition Soviet border guards had attempted to preserve until $1991 .^{5}$

In the course of our conversations, both Shahriyor and Baktygül frequently referred to the Soviet past, and socialism in particular, as points of reference that unite the people of Gorno-Badakhshan and make them distinct from those on the Afghan side of the Panj. Shahriyor's and Baktygül's use of certain terminology is tied to their age - both are over fifty - and therefore to the fact that they personally experienced and remember life in the Soviet Union. However, many of my younger interlocutors described similar forms of connectedness based on their years-long experiences as labour migrants in Russia. These experiences,

5 The Soviet border guards were followed by Russian troops who protected the border along the Panj until 2005. In Baktygül's opinion, these Russian border guards should again return and replace the allegedly corrupt and incompetent Tajik border guards. 
often also linked to being treated as second-class migrants, had left them with ambivalent attitudes towards Russia as a state, but also with a strong feeling of intimacy towards the Russian language and culture. A sense of disconnectedness from the Afghan side of the Panj is therefore not simply a historical phenomenon that will dissolve in the course of post-Cold War globalization, as envisaged by President Rahmon and the Aga Khan. The re-emphasis on the boundary is also a contemporary process and one of the outcomes of a particular transregional connection between Gorno-Badakhshan and Russia.

\section{Language and locality beyond bridges}

Existing studies on language at the Tajik-Afghan frontier (e.g., Wurm 1996; Bliss 2006: 90-103; Beck 2013) tend to map different languages onto specific geographical spaces. In many ways, such an approach walks in the footsteps of Soviet attempts to attribute languages and, as a result, ethnicity, to particular republics, regions, and districts (Smith 1998: 1-13). Pennycook (2010: 130) argues that the definition of locality as a "mappable construct" allows for the recognition of glossodiversity, or the multiplicity of languages. However, he also maintains that such an approach does not pay sufficient attention to the semiodiversity, or the multiplicity of meanings within a language.

The importance of Pennycook's statement for an understanding of current processes at the Tajik-Afghan frontier becomes, for instance, visible in the course of presidential visits to the region. Speaking to different audiences, President Rahmon measures different degrees of loyalty in terms of alignment with his policies and the state, which is defined through Tajik language and culture. However, this does not mean that people in Gorno-Badakhshan simply project their agreement or disagreement onto Tajik as a positive or negative language of state ideology. In contrast, Tajik, and with it its words and sounds, evokes a multiplicity of meanings that include its role as a language of religion and ritual, a language of poetry, a language of historical significance indicative of a past and present Persianate connection, and sometimes also a language of current political opportunity and oppression.

In a similar vein, the Aga Khan's encounters and his use of English at the Tajik-Afghan frontier are far from being single-layered. In this regard, the English language's role as indexing "economic globalization" (Heller 2010) and "international development" (Pennycook 1994) is only the most obvious part of the story. In addition, English is also seen as the language of the Aga Khan, a descendant of the Prophet Muhammad, whose words have a deeply esoteric meaning (Bolander 2016). However, English also indexes "foreign 
intervention" at a former Cold War boundary and plays a mediating role in the supposed reunion of speakers of local languages.

Yet it remains unclear what these "local languages" even are. In competing ascriptions of meaning, they are mapped onto the Tajik-Afghan frontier as a cluster of micro-regions that were separated in the course of Cold War boundary-making. At the same time, both historically established and new forms of mobility from Gorno-Badakhshan and back challenge such ascriptions (see also Bolander, this issue). For instance, encounters between Shughni rappers, who produce their music in Moscow and have their audiences in Gorno-Badakhshan, ${ }^{6}$ can only be called "local" if we understand "locality" as going far beyond context (Pennycook 2010: 128). Similarly, close historical and present-day ties to Russian have shaped the multiple meanings of languages in Gorno-Badakhshan as integral parts of the region and of a world beyond. In this regard, Russian refers to positive and negative aspects of Soviet history, border security, the sufferings of labour migrants, and literacy. At the same time, Russian also halts at the Panj and thus symbolizes a specific form of connectedness that is defined through the absence and exclusion of the Afghan side of the river.

\section{Conclusion}

In this article I conceptualize the Tajik-Afghan frontier in Tajikistan's GornoBadakhshan region as a "contact zone" in which different actors engage in communicative encounters. I take the construction of bridges across the Panj as an example and point of departure to analyse how these actors envisage processes of development and globalization, and to discuss the roles that language ideologies play in the course of such encounters. In this regard I maintain that, following Pennycook (2010), a focus on language as local practice does not only offer a take on the Tajik-Afghan frontier as marked by a high degree of different languages, but by multiple meanings within and beyond these languages. As a result I argue that highlighting the locality of languages at the Tajik-Afghan frontier provides us with the opportunity to explore them as tied to specific communicative encounters in semiotized time and space. Consequently, the standard perception of languages as distinct and stable entities takes a backseat. In a similar vein, I argue that the terms that we use to describe specific languages are polysemic and rarely refer to one "thing". I suggest that this point not only has implications for the study of the Tajik-Afghan frontier, but also for a broader scholarship of

6 A prominent example is the Moscow-based Pamiri rapper Dorob-YAN's, who has become widely popular in Gorno-Badakhshan in recent years. 
Central Asia in which, for instance, specific linguistic identities often serve as an entry point to explore ethnicity.

I maintain that languages at the Tajik-Afghan frontier are local, yet not isolated practices. They variously intersect with other local practices that can be roughly defined as political, religious, economic, and so forth. I argue that different forms of global connections come into the picture precisely in the course of such moments of intersection within communicative encounters. The "friction" (Tsing 2005: 5) that occurs during communication across difference and in moments of diversely intersecting and sometimes contradictory practices fuels the emergence of multiple meanings, not only with regard to language, but to a range of practices. Actors at the Tajik-Afghan frontier are thus eager to (re-)connect to South Asia, yet hesitant to open the border. They are loyal citizens of Tajikistan, yet unwilling to speak the president's language. They love Russian literature, but hate having to work as migrant labourers in Moscow. And they consider the Aga Khan's English words wise, but firmly stick to "their" bank of the river.

Acknowledgements: This article is based on fieldwork conducted in Tajikistan from 2008 to 2013. I am indebted to the Burgergemeinde Bern and the UniBern Forschungsstiftung for generously supporting my research in Central Asia. For support and comments on previous versions of this paper I am particularly thankful to Brook Bolander, Sebastian Muth, Madeleine Reeves, and Tobias Kraudzun.

\section{References}

AKDN 2002. Aga Khan and Tajik and Afghan leaders open bridge into Afghanistan. Akdn.org. http://www.akdn.org/press-release/aga-khan-and-tajik-and-afghan-leaders-open-bridgeafghanistan (accessed 2 July 2017).

AKDN 2006. Inauguration of the Ishkashim bridge. Akdn.org. http://www.akdn.org/speech/hishighness-aga-khan/inauguration-ishkashim-bridge (accessed 2 July 2017).

AKDN 2011. Tajik and Afghan officials inaugurate Vanj Bridge built by AKDN as part of crossborder initiatives. Akdn.org. http://www.akdn.org/Content/1066 (accessed 2 July 2017).

Alastair, Pennycook. 1994. The cultural politics of English as an international language. London: Longman.

Amidkhonov, Ofarid. 2013. Cross-border trade along the river Pyanj in two Badakhshans. MA thesis. OSCE Academy Bishkek.

Bahry, Tajik-Afghan Stephen A. 2016. Societal multilingualism and personal plurilingualism in Pamir Tajikistan's complex language ecology. In Elise S. Ahn \& Juldyz Smagulova (eds.), Language Change in Central Asia, 125-148. Berlin: DeGruyter.

Barfield, Thomas. 2010. Afghanistan: A cultural and political history. Princeton: Princeton University Press.

Baud, Michiel \& van Schendel. Willem. 1997. Towards a comparative history of borderlands. Journal of World History 8(2). 211-242. 
Beck, Simone. 2013. A sociolinguistic assessment of the Roshani speech variety in Afghanistan. Language Documentation \& Conservation 7. 235-301.

Bergne, Paul. 2007. The birth of Tajikistan: National identity and the origins of the republic. London and New York: I.B. Tauris.

Bliss, Frank. 2006. Social and economic change in the Pamirs (Gorno-Badakhshan, Tajikistan). London: Routledge.

Blommaert, Jan. 2007. Sociolinguistic scales. Intercultural Pragmatics 4(1). 1-19.

Blommaert, Jan, Elina Westinen \& Sirpa Leppänen. 2014. Further notes on sociolinguistic scales. Tilburg Papers in Culture Studies 89. https://www.tilburguniversity.edu/upload/ a18771ee-18f5-4b62-88c9-8ddb1cd3dbc3_TPCS_89_Blommaert-Westinen-Leppanen.pdf (accessed 2 July 2017).

Bolander, Brook. 2016. English language policy as ideology in multilingual Khorog, Tajikistan. In Elisabeth Barakos \& Johann W. Unger (eds.), Discursive approaches to language policy, 253-274. London and New York: Palgrave Macmillan.

Clifford, James. 1997. Routes: Travel and translation in the late twentieth century. Cambridge: Harvard University Press.

Curzon, George Nathaniel. 2005 (1896). The Pamirs and the source of the Oxus. London: Royal Geographical Society (Reprint: Elibron Classics Series, Adamant Media Corporation).

De Danieli, Filippo. 2011. Counter-narcotics policies in Tajikistan and their impact on state building. Central Asian Survey 30(1). 129-145.

Dodykhudoeva, Leila. 2002. The socio-linguistic situation and language policy of the Autonomous Region of Mountainous Badakhshan: The case of the Tajik language. Linguapax.org. http://www.linguapax.org/wp-content/uploads/2015/09/CMPL2002_T2_ Dodykhudoeva.pdf (Accessed 2 July 2017).

Epkenhans, Tim. 2016. The origins of the civil war in Tajikistan: Nationalism, Islamism and violent conflict in post-Soviet space. Lanham: Lexington Books.

Evans, Rosalind. 2010. The perils of being a borderland people: On the Lhotshampas of Bhutan. Contemporary South Asia 18(1). 25-42.

Fragner, Bert. G. 1999. Die "Persophonie": Regionalität, Identität und Sprachkontakt in der Geschichte Asiens. Berlin: Das Arabische Buch.

Heathershaw, John. 2009. Post-conflict Tajikistan: The politics of peacebuilding and the emergence of a legitimate order. London and New York: Routledge.

Heller, Monica. 2010. The commodification of language. Annual Review of Anthropology 39. 101-114. Hirsch, Francine. 2005. Empire of nations: Ethnographic knowledge and the making of the Soviet Union. Ithaca and London: Cornell University Press.

Hodgson, Marshall G. S. 1977. The venture of Islam: Conscience and history in a world civilization (The Gunpowder Empires and Modern Times vol. 3). Chicago: University of Chicago Press.

Karabaev, Daniyar \& Elise S. Ahn. 2016. Language-in-education: A look at Kyrgyz language schools in the Badakhshan province of Tajikistan. In Elise S. Ahn \& Juldyz Smagulova (eds.), Language Change in Central Asia, 149-168. Berlin: DeGruyter.

Kellner-Heinkele, Barbara \& Jacob M. Landau. 2012. Language politics in contemporary Central Asia: National and ethnic identity and the Soviet legacy. London and New York: I.B. Tauris.

Khuseynova, Gulchekhra. 2013. Social and economic impacts of labor migration on migrants' households in Tajikistan: Working out policy recommendations to address its negative effects. Center for Public Policy Administration Capstones 26. http://scholarworks.umass. edu/cppa_capstones/26 (Accessed 2 July 2017). 
Maertens, Carolin. 2014. No debt, no business: The social and moral dimension of retail trade in Ishkoshim, Tajikistan. MA thesis. University of Tübingen.

Manetta, Emily. 2011. Journey into Paradise: Tajik representations of Afghan Badakhshan. Central Asian Survey 30(4). 371-387.

Marcus, George E. 1995. Ethnography in/of the world system: The emergence of multi-sited ethnography. Annual Review of Anthropology 24. 95-117.

Mostowlansky, Till. 2012. Making Kyrgyz spaces: Local history as spatial practice in Murghab (Tajikistan). Central Asia Survey 31(3). 251-264.

Mostowlansky, Till. 2016. Humanitarianism across mountain valleys: "Shia aid" and development encounters in northern Pakistan and eastern Tajikistan. In Hermann Kreutzmann \& Teji Watanabe (eds.), Mapping transition in the Pamirs, 229-244. Dordrecht: Springer.

Mostowlansky, Till. 2017. Azan on the moon: Entangling modernity along Tajikistan's Pamir Highway. Pittsburgh: University of Pittsburgh Press.

Muth, Sebastian. 2014a. Linguistic landscapes on the other side of the border: Signs, language and the construction of cultural identity in Transnistria. International Journal of the Sociology of Language 227. 25-46.

Muth, Sebastian. 2014b. War, language removal and self-identification in the linguistic landscapes of Nagorno-Karabakh. Nationalities Papers 42(1). 63-87.

Nadkarni, Maya \& Olga Shevchenko. 2004. The politics of nostalgia: A case for comparative analysis of post-socialist practices. Ab Imperio 4(2). 487-519.

Nourzhanov, Kirill \& Christian Bleuer. 2013. Tajikistan: A social and political history. Canberra: ANU E Press.

Nunan, Timothy 2016. Humanitarian invasion: Global development in cold war Afghanistan. Cambridge: Cambridge University Press.

Omoniyi, Tope. 2004. The sociolinguistics of borderlands: Two nations, one community. Trenton and Asmara: Africa World Press.

Pavlenko, Aneta. 2008. Multilingualism in post-Soviet countries: Language revival, language removal and sociolinguistic theory. International Journal of Bilingual Education and Bilingualism 11(3-4). 275-314.

Pennycook, Alastair. 2010. Language as a local practice. London and New York: Routledge.

Pratt, Mary Louise. 2008 (1992). Imperial eyes: Travel writing and transculturation. London and New York: Routledge.

Prezident 2011. Sukhanronī hangomi iftitohi puli miyoni Tojikiston va Afghoniston. Prezident.tj. http://www.prezident.tj/node/592 (accessed 2 July 2017).

Prezident 2012. Sukhanronī hangomi muloqot bo sokinoni Viloyati Kūhistoni Badakhshon. Prezident.tj. http://www.prezident.tj/node/3446 (accessed 2 July 2017).

Reeves, Madeleine. 2014. Border work: Spatial lives of the state in rural Central Asia. Ithaca and London: Cornell University Press.

Remtilla, Aliaa. 2012. Re-producing social relations: Political and economic change and Islam in post-Soviet Tajik Ishkashim. PhD diss. University of Manchester.

Robinson, Paul \& Jay Dixon. 2013. Aiding Afghanistan: A history of Soviet assistance to adeveloping country. New York: Columbia University Press.

Saikal, Amin. 2012. Modern Afghanistan: A history of struggle and survival. London: I.B. Tauris.

Shaw, Charles. 2011. Friendship under lock and key: The Soviet Central Asian border, 1918-34. Central Asian Survey 30(3-4). 331-348.

Smith, Michael G. 1998. Language and power in the creation of the USSR, 1917-1953. Berlin: De Gruyter Mouton. 
Steinberg, Jonah. 2011. Isma'ili modern: Globalization and identity in a Muslim community. Chapel Hill: North Carolina Press.

Straub, David. 2013. The Ismailis and Kirghiz of the upper Amu Darya and Pamirs in Afghanistan: A micro-history of delineating international borders. MA thesis. Indiana University.

Straub, David. 2014. Deconstructing communal violence during the civil war in Tajikistan: The case of the Pamiris. In Sevket Akyildiz \& Richard Carlson (eds.), Social and cultural change in Central Asia: The Soviet legacy, 174-187. London and New York: Routledge.

Tasneem 2002. Testimony: Aga Khan opens bridge between Afghanistan and Tajikistan. Ismaili. net. http://ismaili.net/timeline/2002/20021103ts.html (accessed 2 July 2017).

Todorova, Maria \& Zsuzsa Gille (eds.) 2010. Post-Communist nostalgia. New York: Berghahn.

Toynbee, Arnold. 1961. Between Oxus and Jumna. London: Oxford University Press.

Tsing, Anna Lowenhaupt. 2005. Friction: An ethnography of global connection. Princeton and Oxford: Princeton University Press.

Van Schendel, Willem \& de Maaker. Erik. 2014. Asian borderlands: Introducing their permeability, strategic uses and meanings. Journal of Borderland Studies 29(1). 3-9.

Wurm, Stephen A. 1996. Shugni as a lingua franca in the Pamir area. In Stephen A. Wurm, Peter Mühlhäusler \& Darrell T. Tryon (eds.), Atlas of languages of intercultural communication in the Pacific, Asia, and the Americas, 947-948. Berlin: De Gruyter Mouton. 